\title{
Improving Torsional Rigidity and Seismic Performance of Tunnel Form Building Structures
}

\author{
Can Balkaya*t, Ihsan Karagoz**, Ismihan Gunal*** \\ *Department of Civil Engineering, Faculty of Engineering and Architecture, Istanbul Gelisim University, Istanbul, Turkey. \\ **Department of Civil Engineering, Faculty of Engineering and Architecture, Beykent University, Istanbul, Turkey. \\ ***Department of Civil Engineering, Faculty of Engineering, Suleyman Demirel University, Isparta, Turkey. \\ (cbalkaya@gelisim.edu.tr, ihsankaragoz@beykent.edu.tr, igunal@gelisim.edu.tr)
}

$¥$ Corresponding Author; Can Balkaya, Department of Civil Engineering, Istanbul Gelisim University, Istanbul, Turkey,

Tel: +90 212422 7020, Fax: +90 212422 7401, cbalkaya@gelisim.edu.tr

Received: 21.04.2017 Accepted: 11.09.2017

\begin{abstract}
Tunnel form buildings, which have shear-wall dominant structural systems, are usually built in countries exposed to substantial seismic risk and very commonly used because of its fast construction technique and low cost. Very limited research has been directed to their experimental studies on 3D behavior, seismic performance, load capacities, collapse mechanisms, and crack propagations. Previous studies indicate that most of the time the first period of the structure is torsion due to construction techniques outer faces is open to take the tunnel forms to out by cranes. This will cause less torsional rigidity, whereas for strong earthquakes, torsional rigidity has to be increased. Four different strengthening techniques, i.e., steel braces, reinforced concrete (RC) infill shear wall, precast concrete shear wall, and RC shear wall at the façade, were applied to improve torsion rigidity. Experimental studies and 3D nonlinear finite element analysis (FEA) were performed on models. The analytical model results, the economy and applicability of construction techniques suggest that steel bracing is the most suitable and practical method to improve torsional rigidity as well as seismic performance. Three-story scaled existing and strengthened experimental models are tested under pushover loads, and the results are compared with 3D nonlinear finite element analysis.
\end{abstract}

Keywords Tunnel form building, shear wall, experimental study, torsional rigidity, seismic performance, pushover loading.

\section{Introduction}

Tunnel form buildings, which have shear-wall dominant structural systems, are usually built in countries exposed to substantial seismic risk and very commonly used in Turkey. They are composed of vertical and horizontal panels set at right angles (Fig. 1), and all wall and floor elements are utilized as primary load-carrying members. Unlike conventional reinforced concrete (RC) structures, tunnel form buildings contain no beams and columns because they can be constructed rapidly and economically. However, despite the abundance of such structures, three-dimensional (3D) experimental studies on 3D behavior, seismic performance, load capacities, collapse mechanisms, and crack propagations have been limited. 3D behavior and seismic performance of the tunnel form structures are previously studied [1-4] by nonlinear finite element analysis (FEA) and modeling. Balkaya and Kalkan [5] indicated that the first period is usually torsion due to construction techniques (Fig. 1) that leave the outer faces open; thus, tunnel forms can be placed and removed using cranes. The result is decreased torsional rigidity, whereas for strong earthquakes, torsional rigidity needs to be increased. The proposed method in this study can be used during new construction after tunnel form construction, or it can be used to increase the existing torsional rigidity and seismic performance of tunnel form buildings by retrofitting. To improve torsional rigidity also increase the seismic performance of the building due to additional rigidities in $\mathrm{x}$ and y directions. 

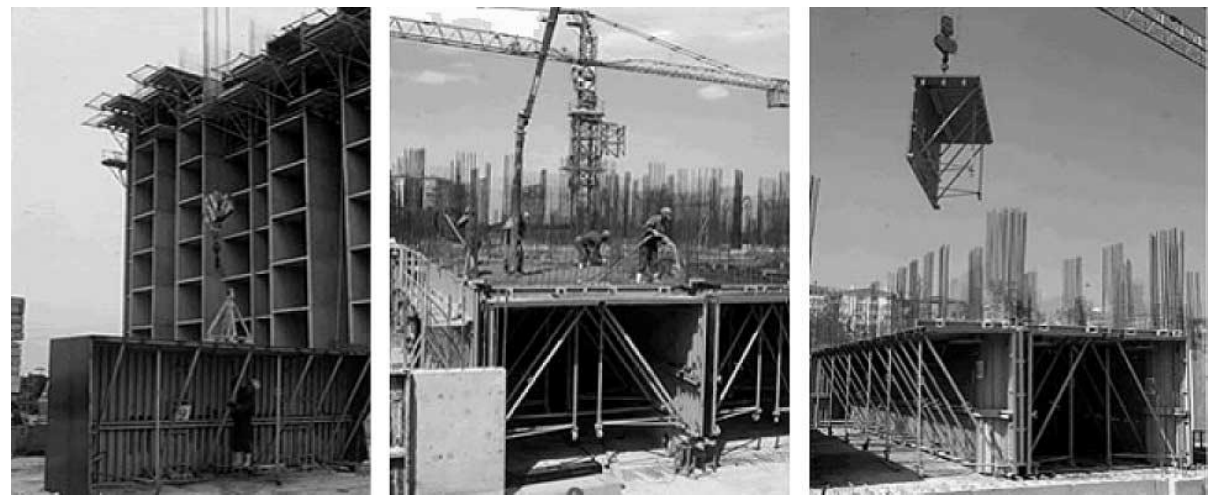

Fig. 1. Tunnel form construction and formwork system.

In previous experimental studies, two four-story scaled building with one span specimens were tested under quasistatic cyclic lateral loading in longitudinal and transverse directions [6]. Yuksel SB [7] tested a full-scale shear wall using a test specimen that was designed to represent the lower stories of structural walls in high-rise tunnel form buildings.

In this study, four strengthening techniques were evaluated to determine if they increased torsional rigidity and seismic performance of shear-wall dominant tunnel form buildings. First, 3D nonlinear FEA was performed using SAP2000 for proposed models. The best strengthening method was selected. Then, for the selected steel brace method the results were compared with experimental tests. $3 \mathrm{D}$ and 1/3-scale three-story models of existing and strengthening tunnel form building with steel braces were tested under pushover loading to observe their seismic behavior and performance, torsional behavior, load capacities, and crack propagations. The concrete quality was C20 (20 MPa). The reinforcement and welded wire fabric was StIII (420), and the steel profile quality was St37. In walls and slabs, $\varnothing 5 / 10$ StIII reinforcements were used in both directions.

\section{Strengthening Techniques for Torsional Rigidity}

Four strengthening techniques, i.e., steel braces, RC infill shear wall, precast concrete shear wall, and RC shear wall at the façade, were studied as shown in Fig. 2b, Fig. 2c, Fig. $2 d$. These techniques addressed the key consideration of closing the gaps due to tunnel form construction techniques.

\subsection{Steel Brace}

Fixing the steel brace at the upper and lower parts of layers within the axis and on the edges of the tunnel form shear walls was intended to increase the rigidity of the building's corner points under lateral loads. Fig. 2a shows the plan view (i.e., $2.0 \times 2.5 \mathrm{~m}^{2}$ ) of the existing tunnel formwork structure, and the steel profiles at the corner box sections are shown in Fig. 2b. The steel profiles are at the corner box sections of $45 \times 45 \times 2$ and the others $40 \times 40 \times 2$ with steel type St37.

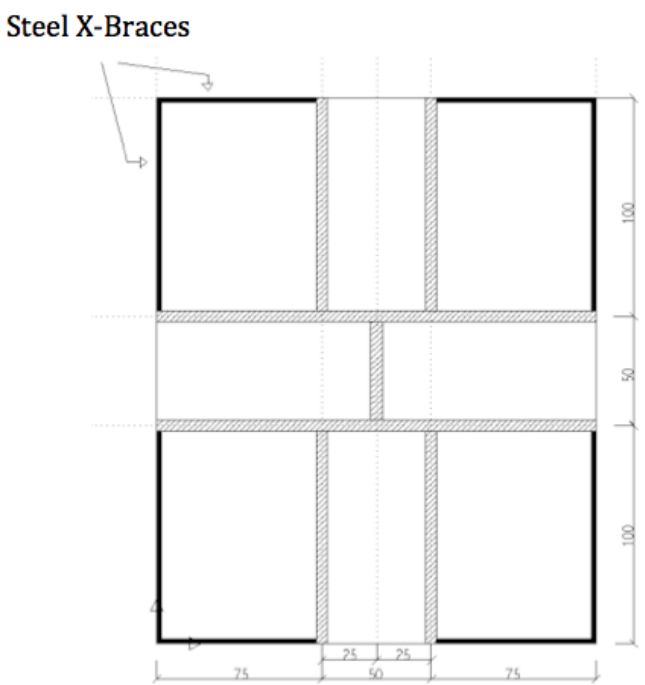

(a) Plan view 


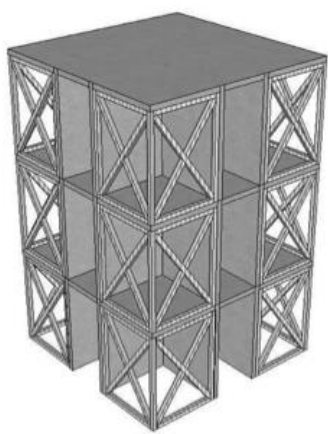

(b) Steel X-braces

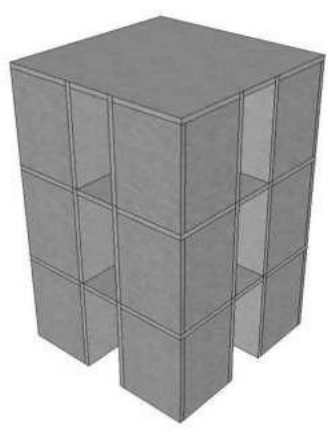

(c) RC or precast walls

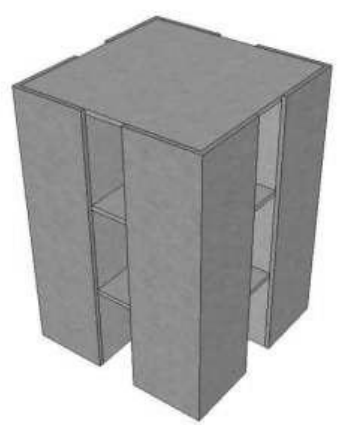

(d) RC walls at façade

Fig. 2. Plan and 3D views of alternative strengthening models.

\subsection{RC Infill Shear Walls}

RC infill shear walls were mounted on the inner axes of the building within the floor-wall axis (Fig. 2c). The partition section was the same as in the existing tunnel formwork building. For constructing shear walls, which could not be constructed because the tunnel formworks were removed at the outer faces, RC infill shear walls were constructed within the edges using anchorages.

\subsection{Precast Concrete Shear Walls}

As it is easy to replace precast concrete shear wall, it was considered as an alternative to RC infill shear wall. The precast concrete shear wall showed the same characteristics as the RC infill shear wall (Fig. 2c) in terms of structural behavior.

\subsection{RC Shear Wall at the Façade}

The RC shear wall at the façade was designed to replace the $\mathrm{RC}$ infill and the precast concrete shear walls. It is anticipated that the RC shear wall at the façade will be easier to construct since it will be constructed through a climbing form on an existing RC building constructed with a tunnel formwork system (Fig. 2d). The anchorages for the climbing form would be prepared before construction. The tunnel formwork would be prepared after the structure was completed.

\section{3D Nonlinear Finite Element Analysis of Models}

3D nonlinear FEA was performed on the four strengthening techniques using SAP2000 structural analysis software. For the non-linear FEA, the shear walls and slabs consisted of shell components. The Mander model was used for concrete $\mathrm{C} 20$ nonlinear material modeling. Nonlinear material properties of concrete, anchorages, and steel profiles (St37) are shown in Fig. 3. In the analysis, in accordance with the loading experiment model, incremental loads were applied at the connection points between the shear walls and floors as $\mathrm{P}$ at the second floor and $2 \mathrm{P}$ at the top floor. The first dynamic period of the existing structure was torsion ( $\mathrm{T}=0.04 \mathrm{~s})$, as shown in Fig. 4. This result indicates that a typical tunnel form building structure model is low torsion-resistant. The 3D behavior, load capacities, collapse mechanisms, crack propagations, and seismic performance of experimental modeling of the existing structure and retrofitted structure models are explained in Section 3.2. The deformed shapes and first periods are shown for steel $\mathrm{X}$-braces and RC/precast walls in Fig. 5a and Fig. 5b, respectively.

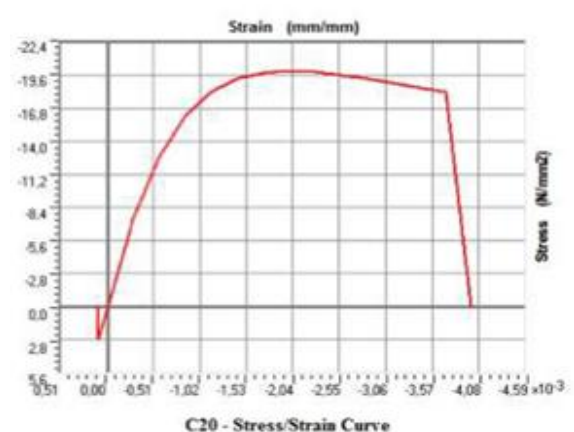

(a) Concrete (C20)

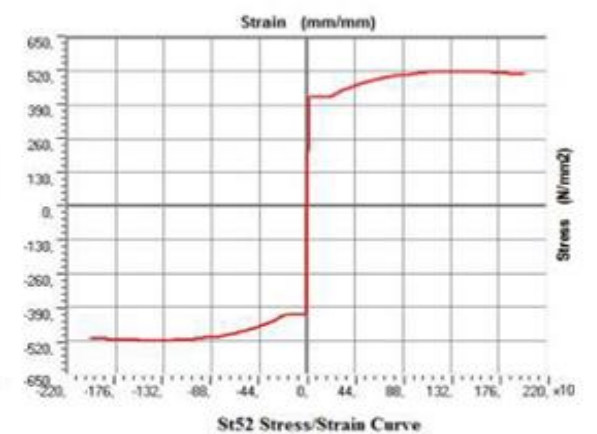

(b) Anchorages (St52)

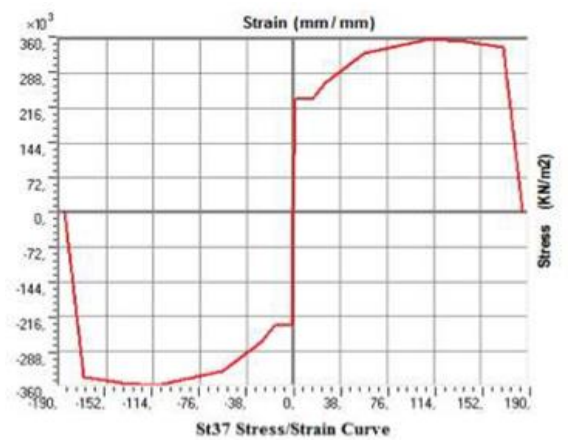

(c) Steel profile (St37)

Fig. 3. Nonlinear material properties. 

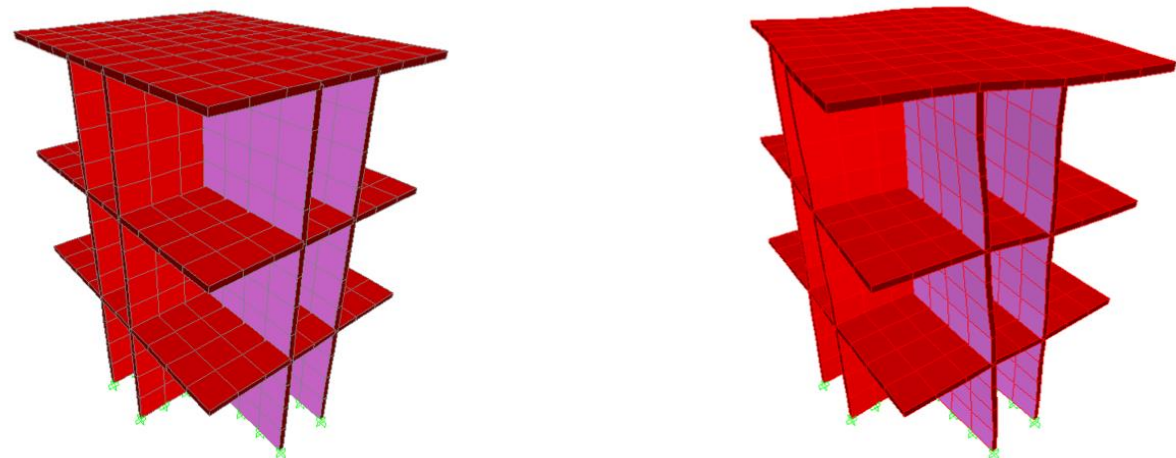

Fig. 4. Existing structure model and first period (torsion $(\mathrm{T})=0.04 \mathrm{~s})$.

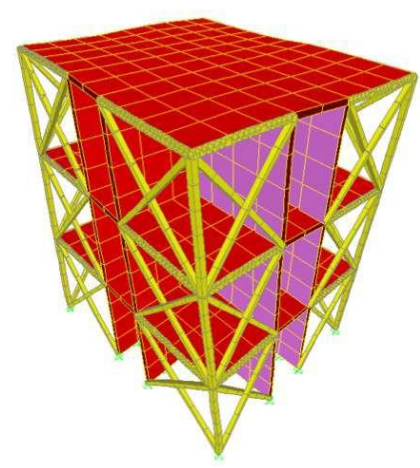

(a) Steel X-braces $(\mathrm{T}=0.25 \mathrm{~s})$

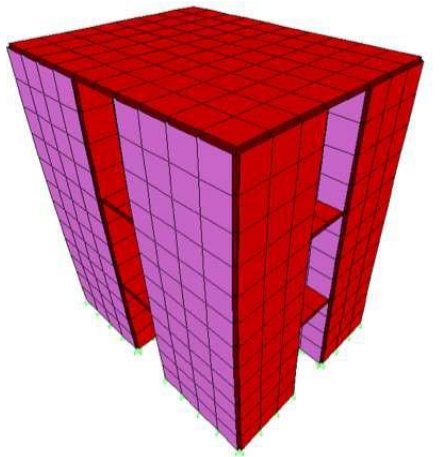

(b) $\mathrm{RC}$ or precast walls (x direction, $\mathrm{T}=0.007 \mathrm{~s}$ )

Fig. 5. Deformed shapes and first periods of structures with steel braces and RC/precast walls.

The results indicate that strengthening with steel $\mathrm{X}$ braces doubles the torsional rigidity of the existing structures. In addition, the steel braces are easy to mount, economical, and add very little structural load on the system. Based on these results, seismic performance experiments were conducted to consider existing tunnel form building structures equipped with steel bracing at the corners.

\section{Experimental Studies}

Experimental studies were performed to observe the impact of strengthening techniques on the torsional rigidity and seismic performance of tunnel form building structures. The 3D behaviour of existing tunnel form buildings with and without strengthening were observed under earthquake loads, and their lateral load capacities, crack patterns, and collapse mechanisms were obtained. Models were constructed, as outlined in Section 2. The tunnel form building plan dimensions were $2.0 \times 2.5 \mathrm{~m}^{2}$ (Fig. 6).

\subsection{Existing Tunnel Form Building Model \\ 4.1.1. Existing Experimental Model}

The existing RC building modelled in this study was constructed and tested in the Earthquake Research Laboratory of Suleyman Demirel University in Isparta, Turkey. The model of the existing three-story tunnel form building had a wall and floor thickness of $5 \mathrm{~cm}$. Based on the actual tunnel form building structures material quality, C20 was used as the concrete mixture. StIII class Ø5 ribbed rebar was used as reinforcement for the RC walls, making a net with $5 \mathrm{~cm}$ intervals. Q131/131 mesh reinforcement, produced by welding the $\varnothing 5$ steel bars at 5 $\mathrm{cm}$ intervals, was used for floors (Fig. 7), and Ø5 reinforcement was added at $15 \mathrm{~cm}$ intervals where the structural bearings emerged. Since the model was created to represent the tunnel formwork building that consisted of walls and slabs as box structure, the depth of concrete cover was $5 \mathrm{~mm}$, and the amount of fine aggregate was increased considering the placement of the concrete. At the base, the reinforcement was $\varnothing 12$ placed at $15 \mathrm{~cm}$ interval in both directions. To eliminate the base movement in the laboratory, the anchorage spaces were set at $50 \mathrm{~cm}$ intervals, as shown in Fig. 8. The anchorages were mounted tightly in the experimental model structures' basement. 


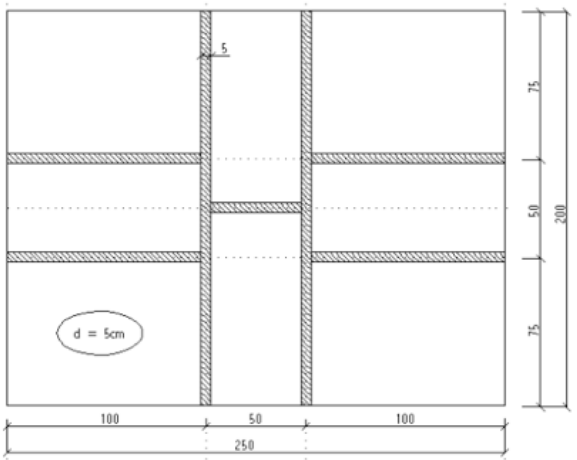

Fig. 6. Experimental tunnel form building model plan (dimensions: $200 \times 250 \mathrm{~cm} 2$ ),

(Wall and floor thickness are 20 and $5 \mathrm{~cm}$, respectively).
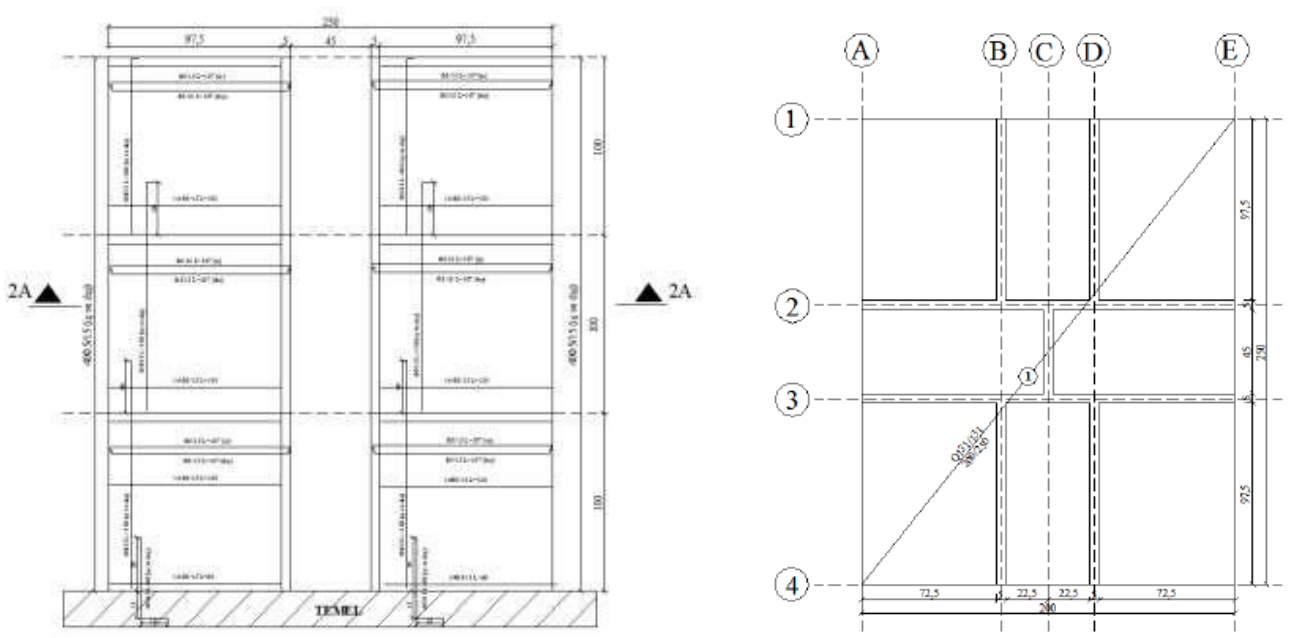

Fig. 7. Tunnel form building shear wall and floor mesh reinforcement.
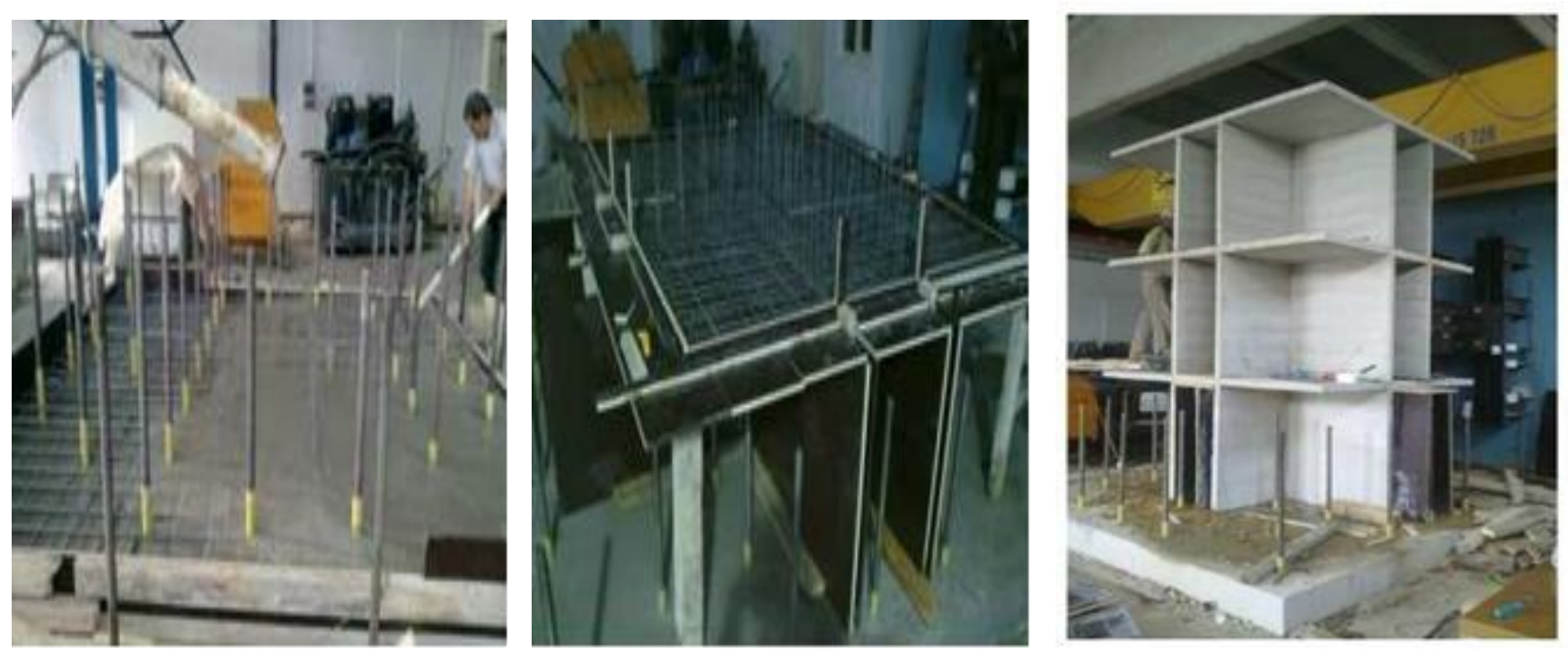

Fig. 8. Construction of 3D model of existing tunnel form building. 


\subsubsection{Loading}

As the loading wall in the laboratory was unilateral, the experimental apparatus for the 3D model of the existing tunnel form building (Fig. 9) was designed to exert pull and push forces for cycling loading on the model by providing a plate and four tie bars on floor levels at the back of the structure, as shown in Fig. 9. Seismic loads were applied as pushover loading, and a load cell platform was arranged to transfer the load to the top two floors by pushing the $2 / 3$ ratio to the upper floor level and the $1 / 3$ ratio to the second floor level.

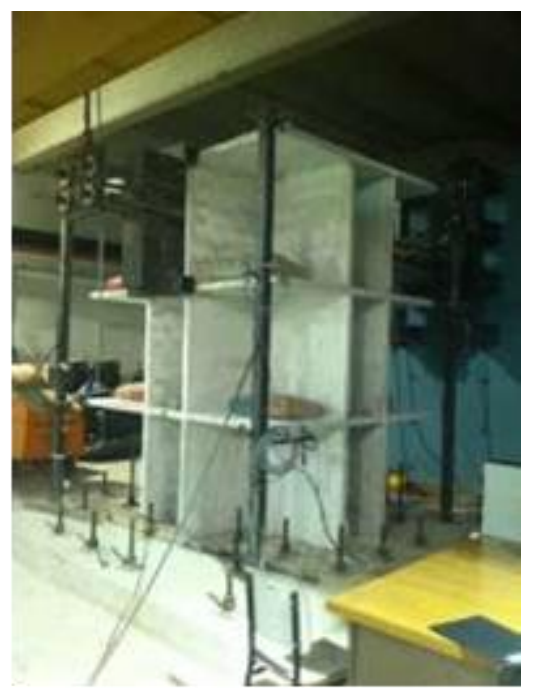

Before applying pushover forces, $50 \mathrm{~kg} / \mathrm{m}^{2}$ loading was applied on each floor slab as additional vertical load using cement bags. Linear variable differential transformers were placed on each floor, including rotation and foundation movements, to measure the basic displacements corresponding to the pushover loads. Horizontal seismic loads were applied to the structure in the form of cyclic pushover loading. Loads were applied to the model until the structure collapsed.

Pushover loads were gradually increased by considering the linear and nonlinear behavior of the structure.

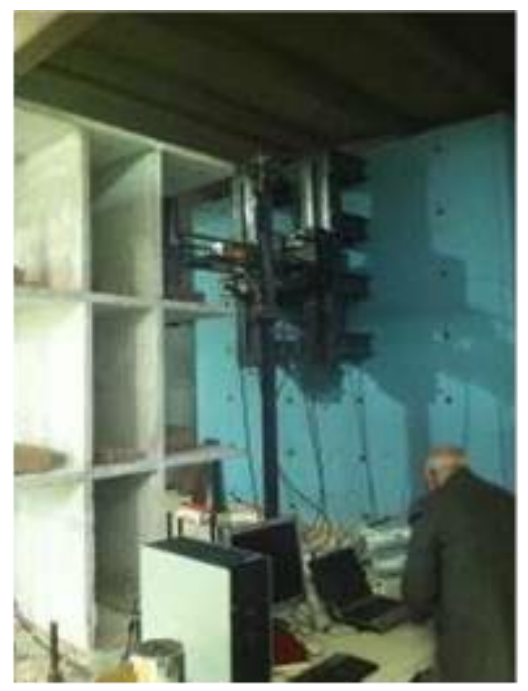

Fig. 9. Pushover loading platform.

\subsubsection{Crack Propagation and Damages}

During loading, cracks were marked according to load cycle number, color, and crack propagation. If cracks occurred due to push forces, they were marked in blue. If cracks occurred due to pull forces, they were marked in red. Crack patterns on the existing tunnel form building model before collapse are shown in Fig. 10.
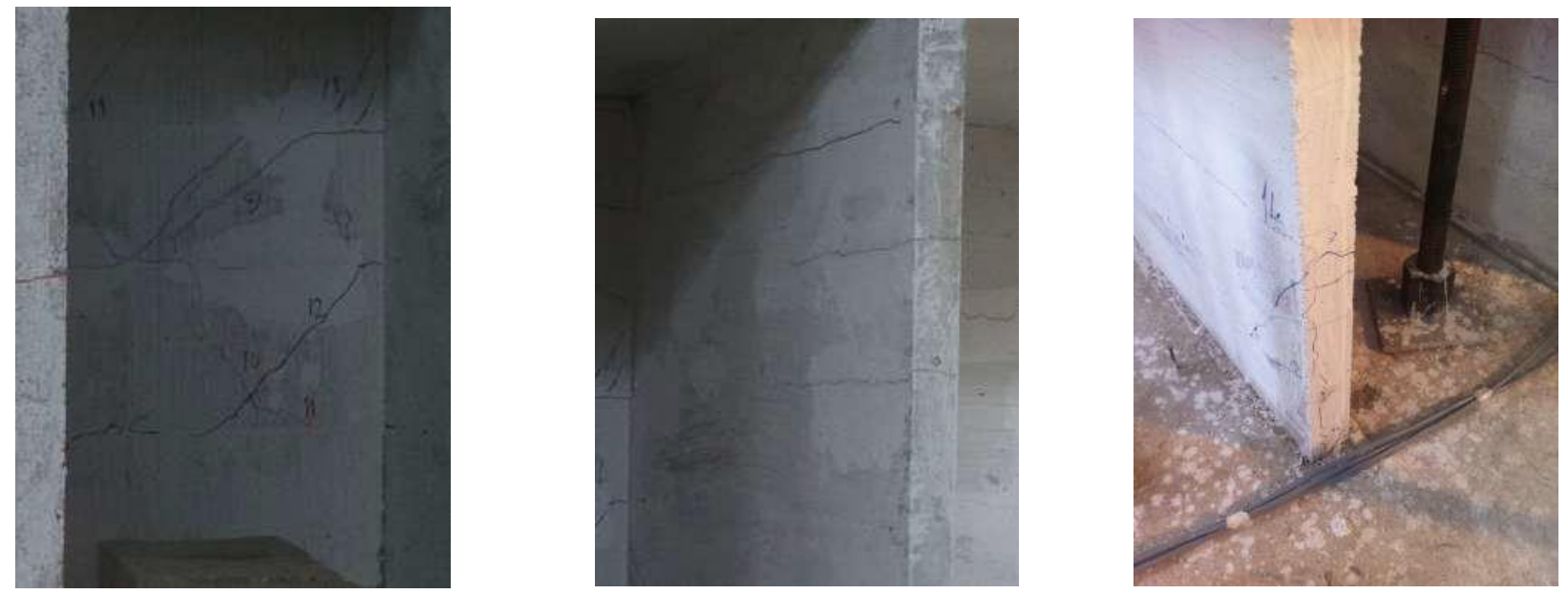

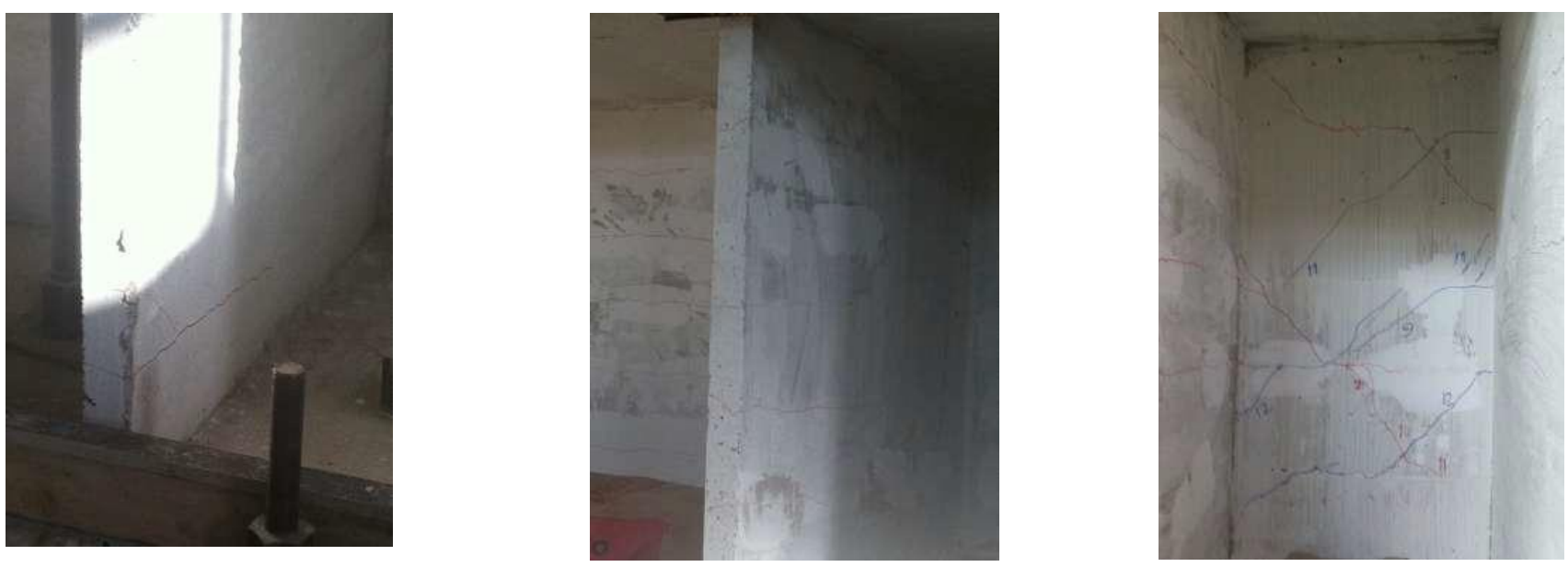

Fig. 10. Crack patterns on the existing tunnel form building model before collapse.

Crack propagations and the cracks emerging after the collapsing force and mechanisms were separately drawn for the shear walls in the direction of force. In addition, the cracks vertical to the direction of force according to the names of shear walls is shown in Fig. 11. To show the 3D effects, the entire shear wall in that direction is shown in Fig. 11. Furthermore, to show the emergence of the cracks in both the surfaces of the shear systems of tunnel formwork, the surfaces are drawn separately in the longitudinal (loading) direction for the P1 and P2 walls (Fig. 11).
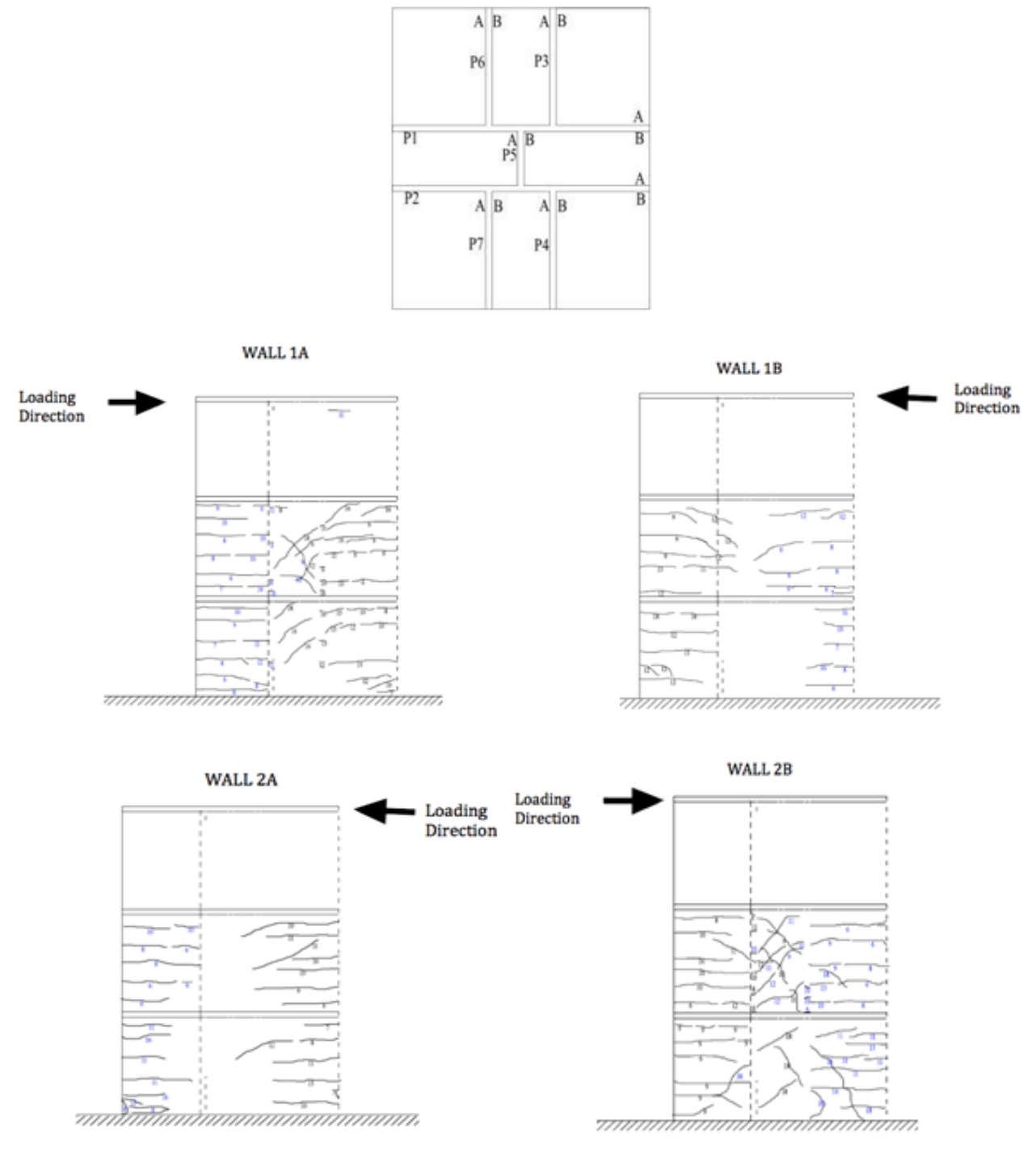

Fig. 11. Wall numbering and crack propagations corresponding to loading steps (step numbers are indicated on the cracks). 
The first cracks were observed as hair cracks at connection points less than 12.9 tons of tensile force. Similar cracks were observed under compressive force. Then cracks emerged in the direction of loading between the first and second floors under 14.9 tons of tensile force. The detailed drawings of other cracks under tensile and compressive forces are shown in Fig. 11. CODA software was used to convey the data from measurement devices in experiments.

\subsubsection{Load Capacity of the Existing Model}

A load-displacement curve of existing tunnel from building experiment model is shown in Fig. 12. The existing structure load capacity is determined under 31.0 tons of force.

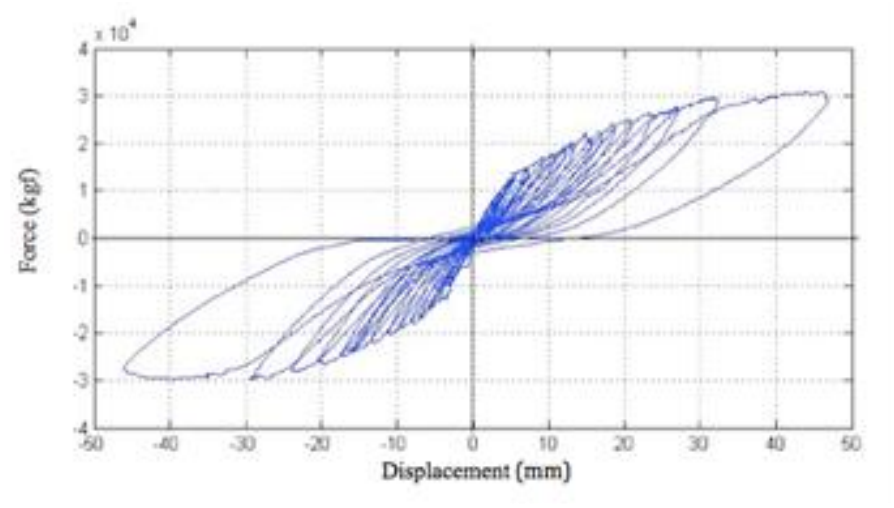

Fig. 12. Load-displacement curve of existing tunnel form building structure model.

\subsection{Strengthened Tunnel Form Building Model}

\subsubsection{Strengthened Experimental Model}

For the torsional rigidity strengthening experimental study, models were constructed in the laboratory and steel $\mathrm{X}$-braces strengthening techniques were applied, as outlined in Section 2. Steel braces were located at the corners of the buildings (Figs. 13 and 2b). The St37 steel material was utilized, as shown in Fig. 3c. To prevent any problems with unilateral loading, the steel frame dimensions were revised to $30 \times 30 \times 2$, the box and crosscomponents were revised to a $30 \times 30 \times 2$ box profile, and the steel in the columns at the edges were replaced with 40 $\times 40 \times 3$ steel profiles.

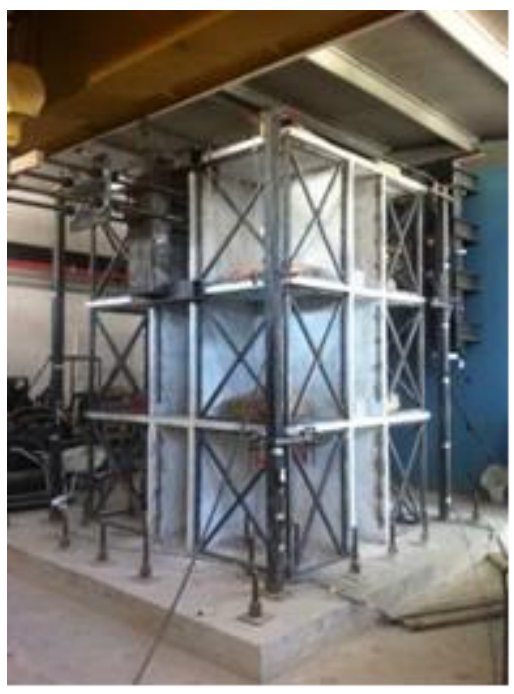

Fig. 13. Experimental model strengthened with X-braces.

\subsection{2. $\quad$ Loading}

The loading platform and vertical loads and instrumentation and wall numbers (Figs. 9 and 11, respectively) that were used in the existing model were used in the strengthened model. Table 1 lists the pushover loading steps.

\subsubsection{Crack Propagation and Damages}

Crack propagations for the strengthened experimental model are shown in Fig. 14.

Table 1. Pushover loading steps.

\begin{tabular}{l|c|c}
\hline \multicolumn{3}{|c}{ Lateral Push-Over Loadings } \\
\hline & Tenslon (ton) & Compression(ton) \\
\hline Step 1: & 5.00 & 5.00 \\
\hline Step 2: & 10.00 & 10.00 \\
\hline Step 3: & 15.00 & 15.00 \\
\hline Step 4: & 17.00 & 17.00 \\
\hline Step 5: & 19.00 & 19.00 \\
\hline Step 6: & 21.00 & 21.00 \\
\hline Step 7: & 23.00 & 23.00 \\
\hline Step 8: & 25.00 & 25.00 \\
\hline Step 9: & 28.00 & 28.00 \\
\hline Step 10: & 31.00 & 31.00 \\
\hline Step 11: & 34.00 & 34.00 \\
\hline Step 12: & 37.00 & 37.00 \\
\hline Step 13: & 38.00 & \\
\hline
\end{tabular}




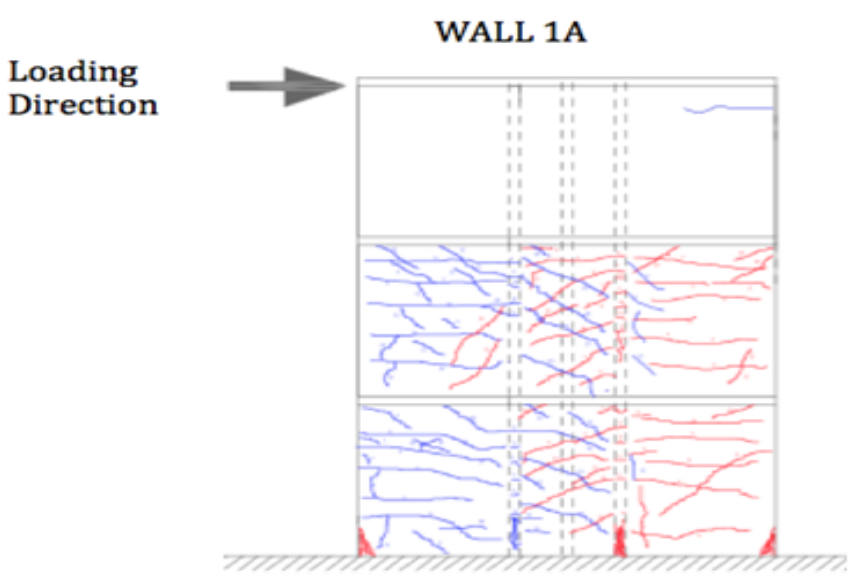

WALL 2A

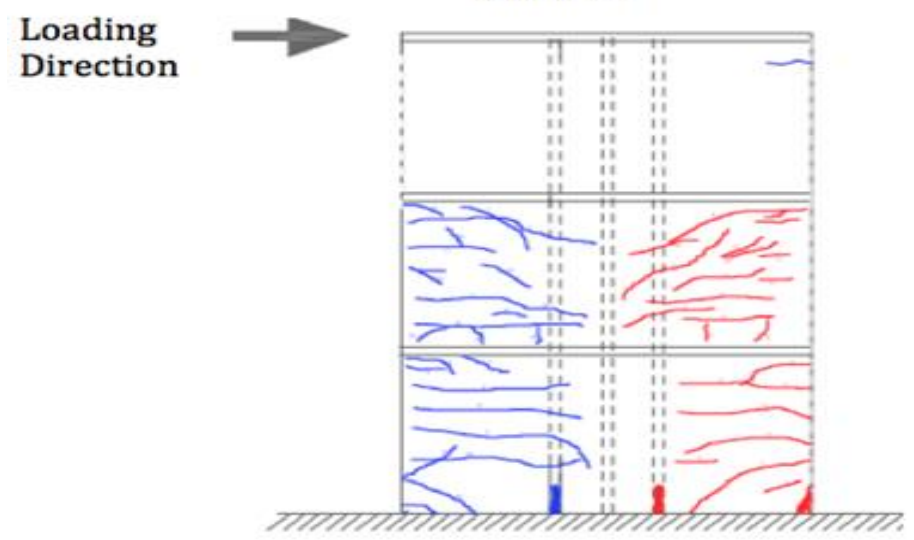

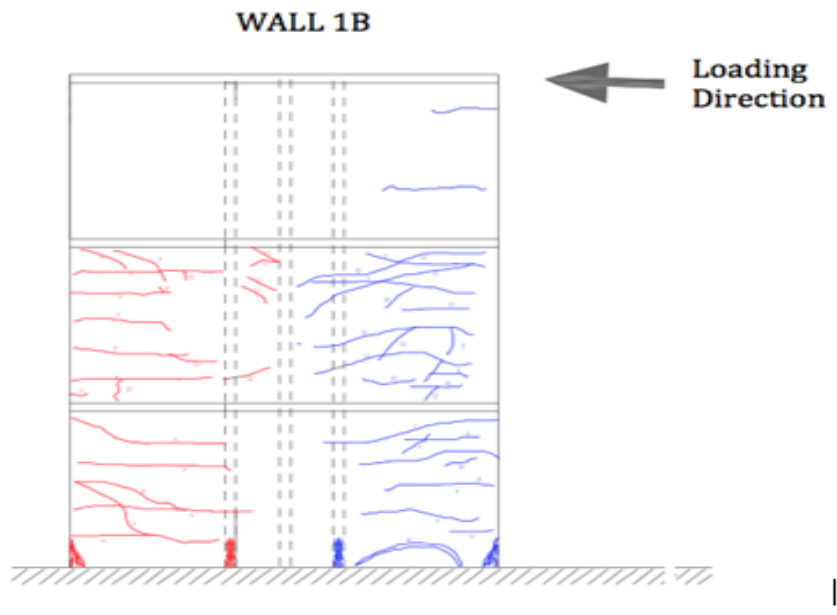

WALL 2B

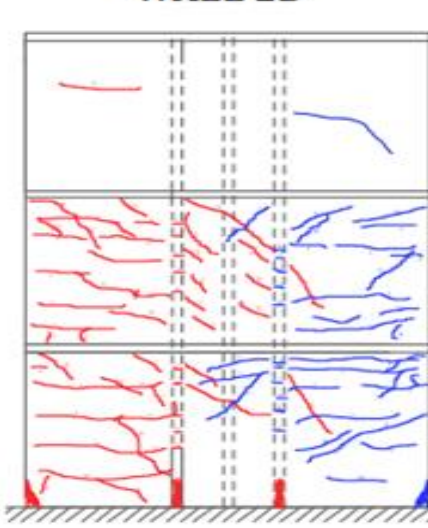

Loading Direction

Fig. 14. Crack propagations for strengthened experimental model.

The first cracks were observed as hair cracks on the lower shear wall in the direction of loading under 17.0 tons of compressive force. In Step 5 and 6, cracks developed in walls vertical to the direction of loading under 19.0 tons of compressive and 21.0 tons of tensile forces, respectively. In Step 9, under 28 tons, noticeable cracks were observed between the basement and shear wall connections. Major damage was observed at first-story shear walls and brace connections at the foundation level (Fig. 16) due to tension-compression coupling effects [3] before the collapse.

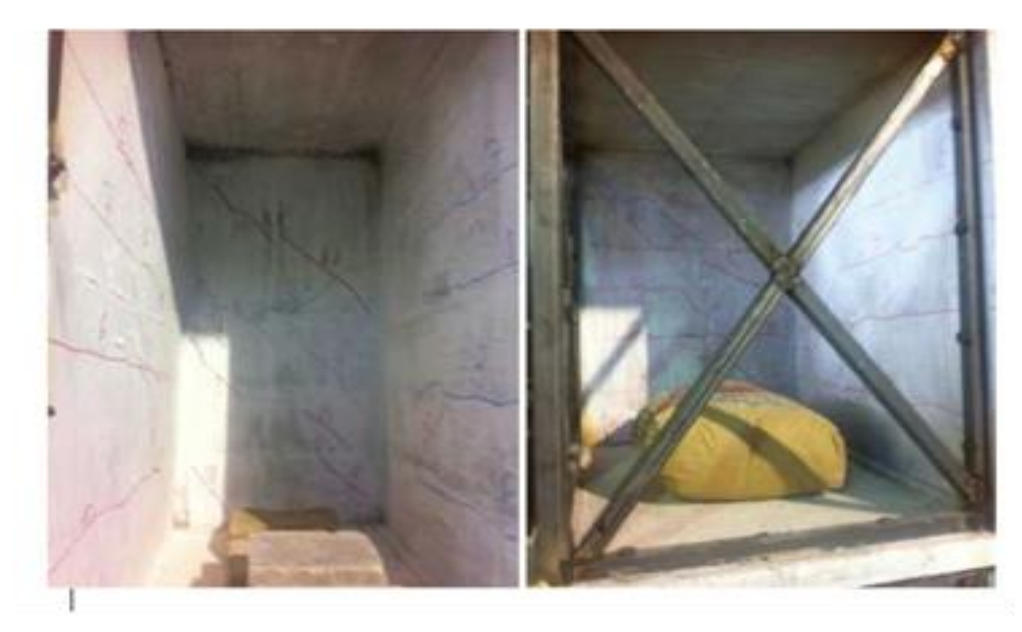

(a) Cracks on second-story shear walls 

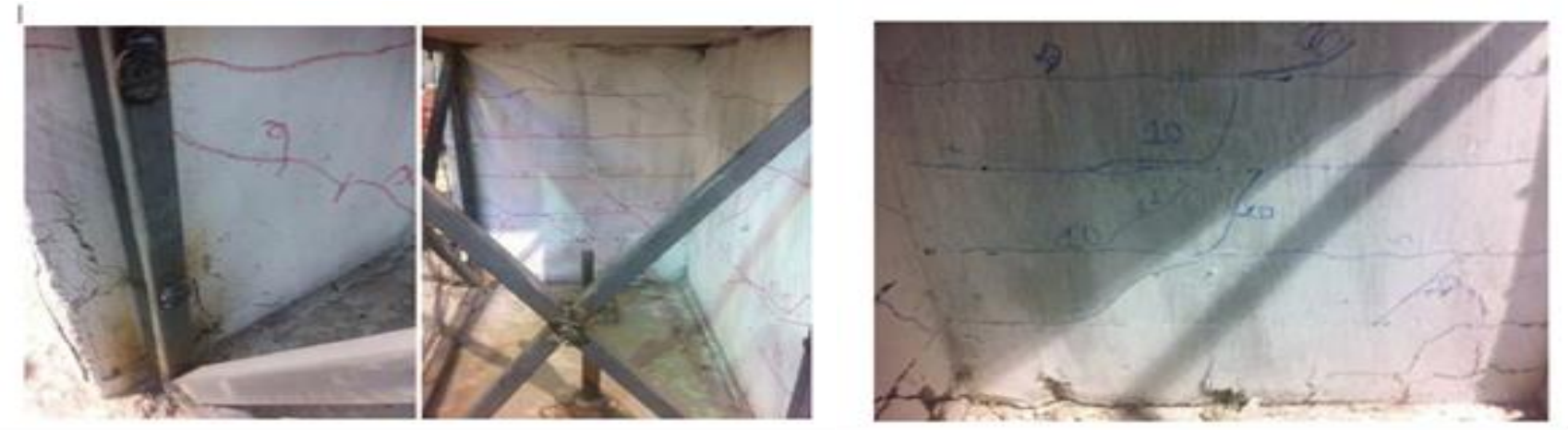

(b) Cracks on first-story shear walls

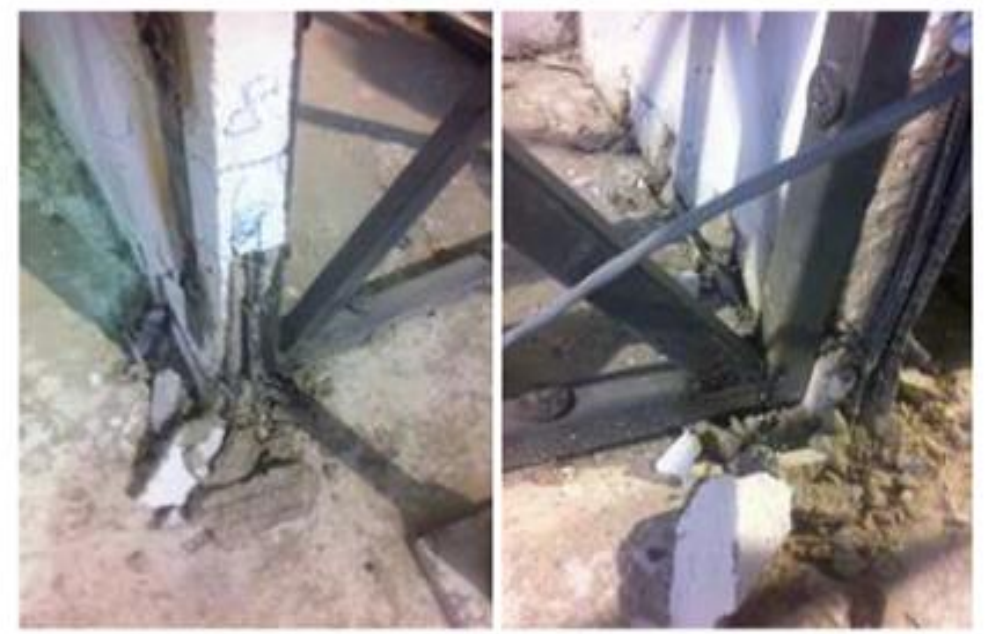

(c) Damage at wall and steel brace connections at the foundation level

Fig. 15. Damage in strengthened model before the collapse.

\subsubsection{Load Capacity of the Strengthened Model}

As shown in Fig. 16, the capacity of the strengthened model was 38.0 tons.

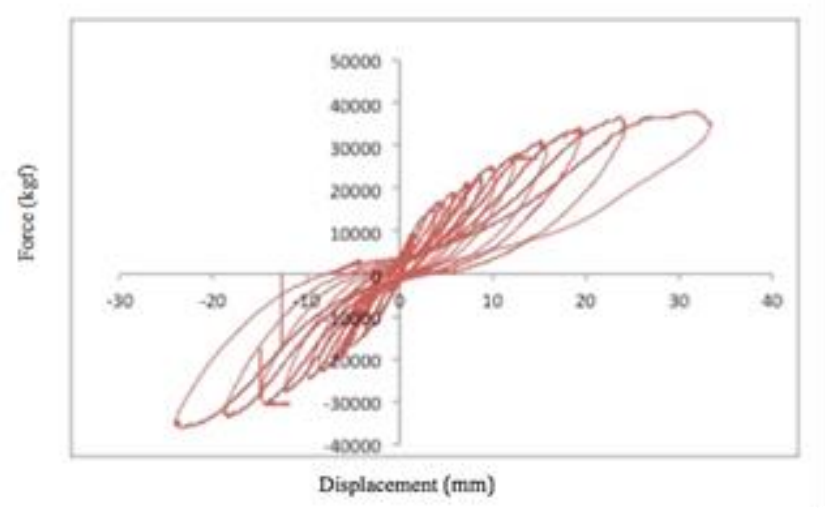

Fig. 16. Load-displacement curve of strengthened tunnel formwork structure model.

\section{Results and Discussion}

3D nonlinear FEA of the existing and strengthened structures was performed using SAP2000 structural analysis software. Material properties, dimensions, and all other information are provided in Section 3. In nonlinear FEA, the shear walls and slabs were modeled as shell components. Considering the rigidity of the load-bearing system, no diaphragm assumption was made for the floors. According to the modal analysis results, the first three modes of the existing structure were determined to be torsion, $\mathrm{x}$ direction, and $\mathrm{y}$ direction. Experimental model studies are performed for the selected steel X-braces strengthening method. In the strengthened steel brace model, the torsion rigidity gradually increased. The system passed from torsion to deflection mode. Pushover loading, in accordance with the loading experiment model, was incrementally applied at the junction points between shear walls and floors. Because of nonlinear FEA, the earthquake performance of the existing and strengthened models was determined to be 32 and 40 tons, respectively. 


\section{Conclusions}

The steel X-braced strengthened tunnel form building model collapsed in the deflection phase rather than the torsion phase, and the crack pattern of the structure differed from that of the existing structure due to the steel bracing components used at the edges. Through strengthening, both the torsional rigidity and the earthquake performance of the structure were improved. In testing the existing experimental model in the laboratory, the collapse load of the strengthened structure was 38 tons, while that of the existing model was 31 tons. In experiments and FEA, the system was removed from the undesired mode of torsion, and increase in torsional rigidity and earthquake performance was observed.

The first natural periods of the structures are generally torsion due to tunnel form construction technique and may lead to damage in major earthquakes. The practical applicability and economy of the method outlined here is essential for both earthquake performance and retrofitting the tunnel formwork structures damaged in earthquake.

The experiments show the earthquake behaviors and collapse mechanisms of the existing tunnel form building structures and strengthened structures. Buildings constructed with a tunnel formwork system first dynamic mode may appear torsion, this situation occurs because of removing the mold in the tunnel formwork systems and transporting it to the upper floor.

The systems developed in this research are recommended for improving the torsional rigidity and earthquake performance of both new construction and retrofitting.

\section{Acknowledgements}

Turkish National Science Foundation (TUBITAK) supported this research, Industrial R\&D Project No 3100355 .

\section{References}

[1] Balkaya C, Schnobrich WC. "Nonlinear 3D behavior of shear-wall dominant RC building structures", Structural Engineering Mech 1993; 1:1-16.

[2] Balkaya C, Kalkan E. "Nonlinear seismic response evaluation of tunnel form building structures", Comput Struct 2003b; 81: 153-65

[3] Balkaya C, Kalkan, E. "Three-dimensional effects on openings of laterally loaded pierced shear walls", ASCE, Journal of Structural Engineering 2004b; 130: 1506-1514.

[4] Balkaya C, Kalkan E. "Estimation of fundamental periods of shear-wall dominant building structures", Earthquake Engineering Structural Dynamics 2003a; 32: $985-98$.

[5] Balkaya C, Kalkan E. "Seismic vulnerability, behavior and design of tunnel form building structures", Engineering Structures 2004a; 26: 2081-2099.

[6] Yuksel SB, Kalkan E. "Behavior of tunnel form buildings under quasi-static cyclic lateral loading", Structural Engineering Mechanics 2007; 27: 99.

[7] Yuksel SB. "Structural behavior of lightly reinforced shear walls of tunnel form buildings", IACSIT International Journal of Engineering Technology 2014; $6: 34-37$. 